\title{
Leaf Structure and Taxonomy of Petunia and Calibrachoa (Solanaceae).
}

\author{
Claudia dos Reis ${ }^{1}$; Maria das Graças Sajo ${ }^{1}$ and João Renato Stehmann ${ }^{2}$ \\ ${ }^{1}$ Departamento de Botânica, IBUNESP, Rio Claro, C. Postal 199, CEP 13506-900, Rio Claro - SP, Brazil; \\ ${ }^{2}$ Departamento de Botânica, ICBUFMG. Av. Antônio Carlos, 6627, CEP 31270-110, Belo Horizonte - MG, Brasil
}

\begin{abstract}
We studied the leaf anatomy of sixteen species of Calibrachoa and eight species of Petunia. In Calibrachoa leaves, the vascular bundles sheath (endodermis) was formed by parenchymatous developed cells, different from those of the mesophyll. In Petunia, this sheath did not show a marked morphological differentiation. The Calibrachoa leaves could be separated according to the type of leaf margins, the distribution of the stomata on leaf surfaces, the organization of the mesophyll and the morphology of the trichomes. Based on these results, an indented dichotomous identification key was elaborated for the species of the genus Calibrachoa.
\end{abstract}

Key words: Solanaceae, Calibrachoa, Petunia, leaf anatomy, taxonomy

\section{INTRODUCTION}

Solanaceae is an important family for possessing countless ornamental, medicinal and nutritious species (Heywood, 1993; Sauer, 1994). Petunia Jussieu, which belong to the subfamily Cestroideae Schltdl - tribe Nicotianeae G. Don. (Hunziker, 1979; Cosa de Gastiazoro, 1991) is a genus with many ornamental species. It is native of South America and is popularly known as the garden petunia, a highly cultivated hybrid for ornamental purposes derivated from a cross between Petunia axillaris (Lamarck) Britton, Sterns \& Poggemburg and P. integrifolia (Hooker) Schinz \& Thellung (Wijsman, 1982).

Studies accomplished during the last decade, concentrating mainly on the genetic improvement of the garden petunia, showed that in Petunia sensu Fries (1911) there wese two genetically distinct groups designated by Wijsman \& Jong
(1985) as two genera: Petunia $(2 \mathrm{n}=18)$ and Stimoryne Rafin. $(2 \mathrm{n}=14)$. According to this work, the garden petunia $(2 n=14)$ was included in the genus Stimoryne. However, as the name Petunia was previously established among horticulturists, Wijsnands et al. (1986) suggested the conservation of $P$. nyctaginiflora Juss. $(2 \mathrm{n}=14)$ as the nomenclatural type of the genus Petunia (Brummitt, 1989) and revalidated the genus Calibrachoa La Llave \& Lex. $(2 \mathrm{n}=18)$. Twelve species remained in the genus Petunia (Ando \& Hashimoto 1996) and 24 were recombined to Calibrachoa (Wijsman, 1990; Stehmann \& Semir, 1997).

In his study on the limits between the genera Petunia and Calibrachoa, Stehmann (1999) confirmed that they wese morphologically and cytologically distinct. Petunia is characterized by an imbricate prefloration, a chromosome number $\mathrm{n}=7$ and seed coat formed by cells with wavy,

\footnotetext{
*Author for correspondence
} 
anticlinal walls. Calibrachoa possesses a conduplicate prefloration, a chromosome number $\mathrm{n}=9$ and seed coat cells with straight, anticlinal walls. Moreover, the species of Calibrachoa are predominantly subarbustive and perennial, while the species of Petunia are mostly herbaceous and annual (Stehmann, 1999).

Although the morphological (Stehmann, 1999), cytogenetic (Wijsman, 1983) and chemical (Elliger et al. 1992) aspects have already been investigated, anatomical information is scarce for the species of the two genera. Cosa de Gastiazoro (1991) studied the anatomical structure of the vegetative organs of some species of Petunia sensu hto, embracing representatives of the two genera; however, the author did not relate the results obtained to the taxonomic alterations of the group. Recently, Watanabe et al. (1999) described for Petunia sensu lato three different seed surface patterns: 1) thick, wavy middle lamellae and anticlinal cell walls (all the species of Petunia sensu Wijsman), 2) thin, wavy middle lamellae embedded in straight anticlinal cell walls $(C$. parviflora and C. pygmaea), and 3) straight middle lamellae and anticlinal cell walls (all the other species of Calibrachoa).

Anatomical studies with representatives of Solanaceae, are those of Ahmad (1964), Roe (1971), Bernardello (1982), Ogundipe (1992) and Cosa de Gastiazoro (1993; 1994).

The present study describes the leaf structure of eight Petunia and sixteen Calibrachoa species with the purpose of pointing out anatomical characters useful for the separation of these two genera and for the characterization of Calibrachoa species.

\section{MATERIAL AND METHODS}

Plant material was collected from its natural habitats in São Paulo, Paraná, Santa Catarina and Rio Grande do Sul States and the vouchers wase deposited in the Herbarium of the Universidade Estadual de Campinas (UEC) under the following specifications: Calibrachoa caesia (Sendtn.) Wijsman, J. R. Stehmann (1946) et al.; $C$. eglandulata Stehmann \& Semir, J. R. Stehmann (1763) et al.; C. elegans (Miers) Stehmann \& Semir, Stehmann (1160) et al.; C. ericifolia (R. E. Fr.) Wijsman, J. R. Stehmann (s/n) et al. (UEC 72579); C. excellens (R. E. Fr.) Wijsman, J. R. Stehmann (1684) \& A. Ippolito; C. heterophylla (Sendtn.) Wijsman, J. R. Stehmann (1826) et al.;
C. humilis (R. E. Fr.) Stehmann \& Semir, J. R. Stehmann (1584) et al.; C. linoides (Sendtn.) Wijsman, J. R. Stehmann (1743, 1950) et al.; $C$. micrantha (R. E. Fr.) Stehmann \& Semir, J. R. Stehmann (2237) \& C. dos Reis; C. ovalifolia (Miers) Stehmann \& Semir, J. R. Stehmann (1584) et al.; C. paranensis (Dusén) Wijsman, J. R. Stehmann (1692) \& A. Ippolito; C. parviflora (Juss.) Wijsman, J. R. Stehmann (1580) et al; $C$. pygmaea (R. E. Fr.) Wijsman, J. R. Stehmann (2048) et al.; C. sellowiana (Sendtn.) Wijsman, J. R. Stehmann (1767, 1774, 1778, 1862, 1894) et al; C. sendtneriana (R. E Fr.) Stehmann \& Semir, J. R. Stehmann (1799) et al; C. spathulata (L. B. Sm. \& Downs) Stehmann \& Semir, J. R. Stehmann (1671) \& A. Ippolito; Petunia altiplana T. Ando \& Hashim., J. R. Stehmann (1876) et al.; P. axillaris (Lam.) Britton, Sterns \&t Poggenb., J. R. Stehmann (1579) et al; P. bonjardinensis T. Ando \& Hashim., J. R. Stehmann (1808) et al; P. exserta Stehmann, J. R. Stehmann (1603); $P$. guarapuavensis T. Ando \& Hashim., J. R. Stehmann (1688) \& A. Ippolito; P. integrifolia (Hook.) Schinz \& Thell., J. R. Stehmann (1836) et $a l$; P. reitzii L. B. Sm. \& Downs, J. R. Stehmann (1741) et al; P. scheideana L. B. Sm. \& Downs, J. R. Stehmann (1721) et al.

Adult leaves, unrelated with the reproductive organs, located between the $3^{\text {rd }}$ and $8^{\text {th }}$ nodes were fixed in FAA 70 (Johansen, 1940). The middle region of the leaves were cut by free hand or by a microtome in the case of material included in paraffin (Johansen, 1940); the sections were stained with astra blue and basic fucsin (Sass, 1951) and mounted in "Entellan" (included material) or glycerinated gelatin (free hand sections).

The diagrams were executed by hand under the optical microscope, using a camera lucida and projection of a micrometric scale. The a JVC video camera coupled to a photomicroscope and a computer.

\section{RESULTS AND DISCUSSION}

The leaves of Petunia and Calibrachoa showed a significant difference. In Calibrachoa species, the parenchymatous sheath that surrounded the vascular bundle (endodermis) was formed by developed cells, different from those of the mesophyll (Fig. 1); in Petunia, the endodermis did not present a marked morphological differentiation (Fig. 2). 

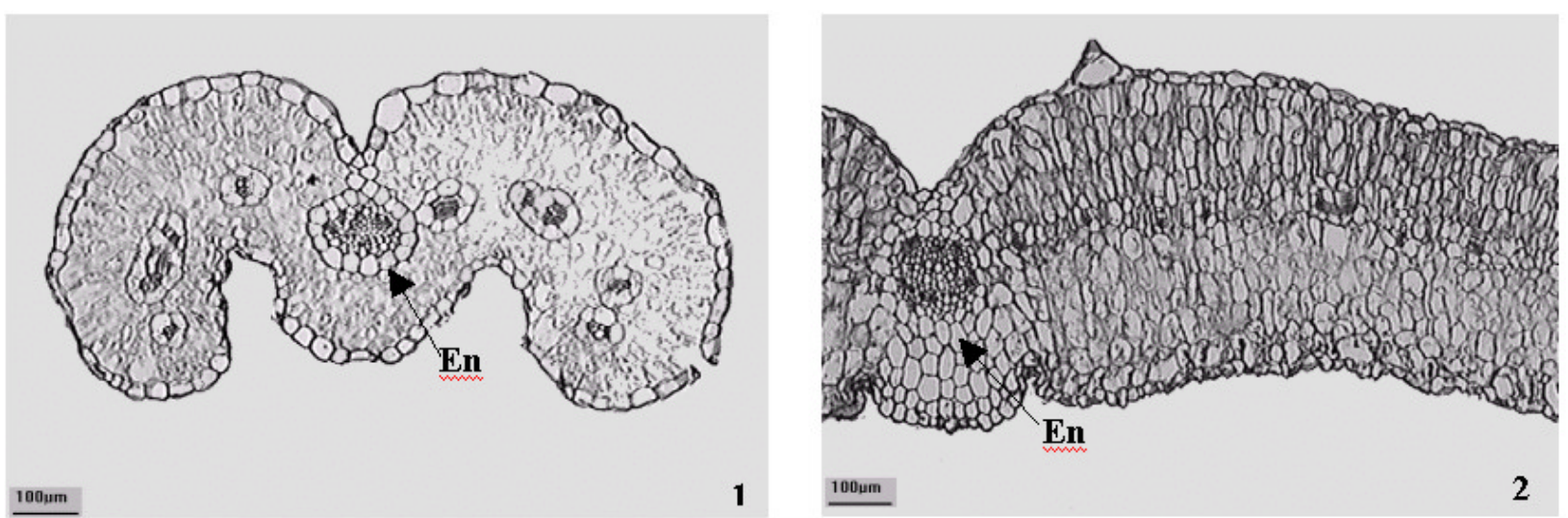

Figures 1-2 - Micrographs of the middle region of leaves of Calibrachoa and Petunia in cross section. 1) Calibrachoa paranensis, 2) Petunia integrifolia. (En=endodermis).

These results brought evidence to support the acceptance of Petunia sensu lato as an artificial genus.

Of the 16 species of Calibrachoa studied (about $70 \%$ of the genus), only in Calibrachoa parviflora and C. pygmaea the endodermis was less developed.

Cosa de Gastiazoro (1991) studied the anatomy of the vegetative organs of Petunia sensu lato but did not report any morphological differences in the endodermis leaves, in spite of having studied species of the two genera. According to the same author, in Petunia the leaf structure was relatively uniform and showed a dorsiventral mesophyll (in most of the species), epidermis formed by isodiametric cells, stomata on both surfaces and glandular, uniseriated trichomes with a stalk of two to six cells. These results could be due to the reduced number of species studied: two from the genus Petunia sensu stricto ( $P$. axillaris and $P$. integrifolia), one from Calibrachoa (P. parviflora) and the other probably from Fabiana ( $P$. patagonica (Speg.) Millan) (Stehmann, 1999).

Different from the reported by Cosa de Gastiazoro (1991) for Petunia, the leaf structure in Calibrachoa is quite diversified, both externally and internally. When observed in a transversal section, they can be revolute (Fig. 3, Table 1), semi-revolute (Fig. 4, Table 1), conduplicate (Fig. 5, Table 1), semi-conduplicate (Fig. 6, Table 1) or plane (Fig. 7, Table 1).

Morphological variations could be observed even among individuals of the same species (Table 1). In C. sellowiana the leaves wese plane, conduplicate or semi-conduplicate and in $C$. linoides they wese plane or semi-revolute. But on both species the mesophyll was always dorsiventral with a palisade parenchyma in the adaxial surface and a spongy parenchyma with lobed cells in the abaxial surface.

Considering the size of the epidermal cells and the distribution of the stomata in the surfaces, it was possible to recognize in Calibrachoa two different groups of leaves (Table 1): one with the epidermis formed by cells of similar sizes and stomata distributed on both surfaces (Fig. 8) and other with larger epidermal cells in the

adaxial surface and stomata only in abaxial surface (Fig. 9). According to Metcalfe \& Chalk (1957), amphistomatic leaves are common in Solanaceae, although Cosa de Gastiazoro (1991; 1993; 1994) described hypostomatic leaves in some species of the family. 

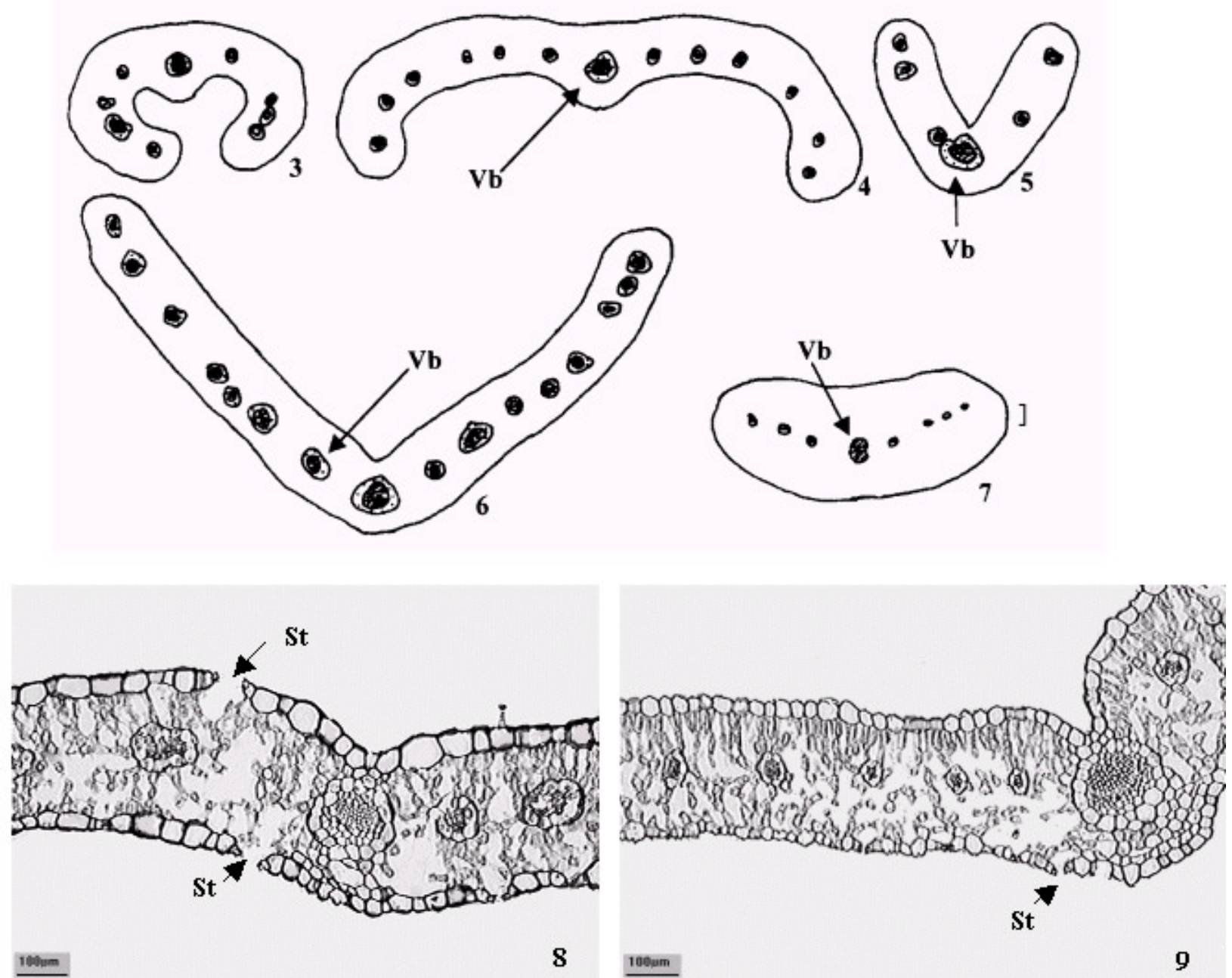

Figures 3-9 - Diagrams and micrographs of the middle region of Calibrachoa leaves in cross section. 3) $C$. ericifolia, 4) C. micrantha, 5, 8) C. sellowiana, 6) C. spathulata, 7) C. pygmaea, 9) C. sendtneriana $(\mathrm{br}=100 \mu \mathrm{m}$, $\mathrm{Vb}=$ vascular bundle, $\mathrm{St}=$ stomata).

Glandular trichomes wese common in Calibrachoa leaves. They presented a basal cell and a stalk that sustained an apical secretory cell (Fig. 10, 11). The cell number of the trichome stalk varies depending on the species. In a same leaf, short trichomes (with a stalk varying between 1-3 cells) and long trichomes (stalk with 4-12 cells) wese found (Table 1). This was the case of $C$. linoides where the number of cells in the stalk varied from 2-9 and 12. The variation in the trichomes size was used by Fries (1911) for differentiating some species like Petunia linoides/P. regnellii and $P$.

variabilis / P. excellens.
Among the studied species, Calibrachoa eglandulata (Table 1) was the only one lacking glandular trichomes. In its leaves there wese uniseriate nonglandular trichomes (Fig. 12) formed by 611 cells. According to Stehmann \& Semir (1997), this species probably lost the capacity to produce secretions, because glandular trichomes wese present in all the remaining species of the genus, as well as in the species of closely related genera, like Petunia and Fabiana. 

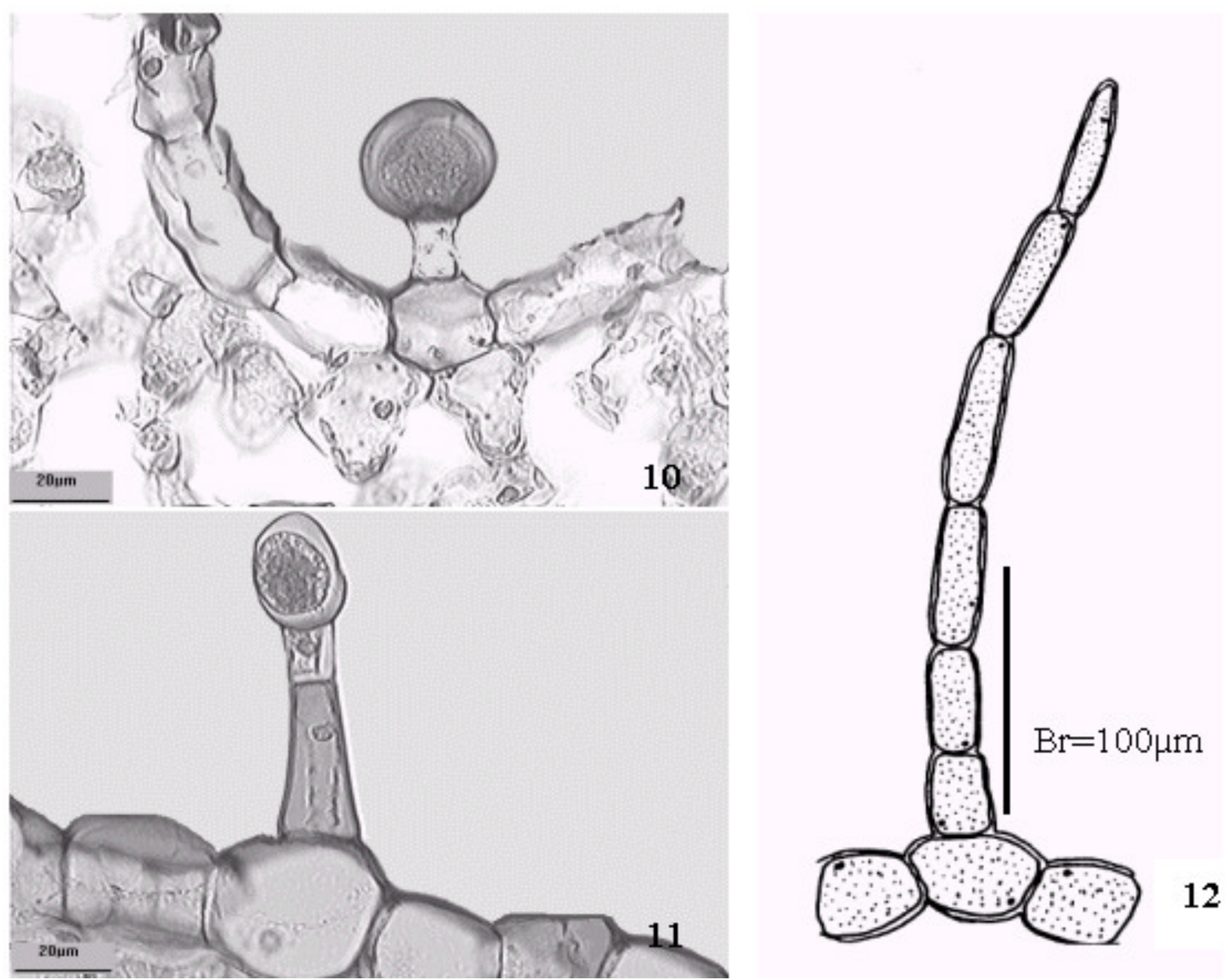

Figures 10-12 - Micrographs of the middle region of leaves of Calibrachoa in cross section. 10) C. ericifolia, 11) C. elegans, 12) C. eglandulata.

Analyzing the organization of the mesophyll, it was possible to separate the leaves of Calibrachoa into four different groups (Table 1), namely: a) leaves with a homogeneous mesophyll formed only by lobed cells of the spongy parenchyma (Fig. 13), b) leaves with a homogeneous mesophyll formed only by palisade parenchyma (Fig. 14), c) leaves with a dorsiventral mesophyll formed by adaxial palisade parenchyma and abaxial spongy parenchyma (Fig. 15) and d) leaves with palisade parenchyma and abaxial lobed cells of the spongy parenchyma (Fig. 16). Dorsiventral mesophyll is the most frequent in Solanaceae, but Cosa de Gastiazoro (1991; 1993; 1994) and Bernardello (1982) described a homogeneous mesophyll for some species of the family. 

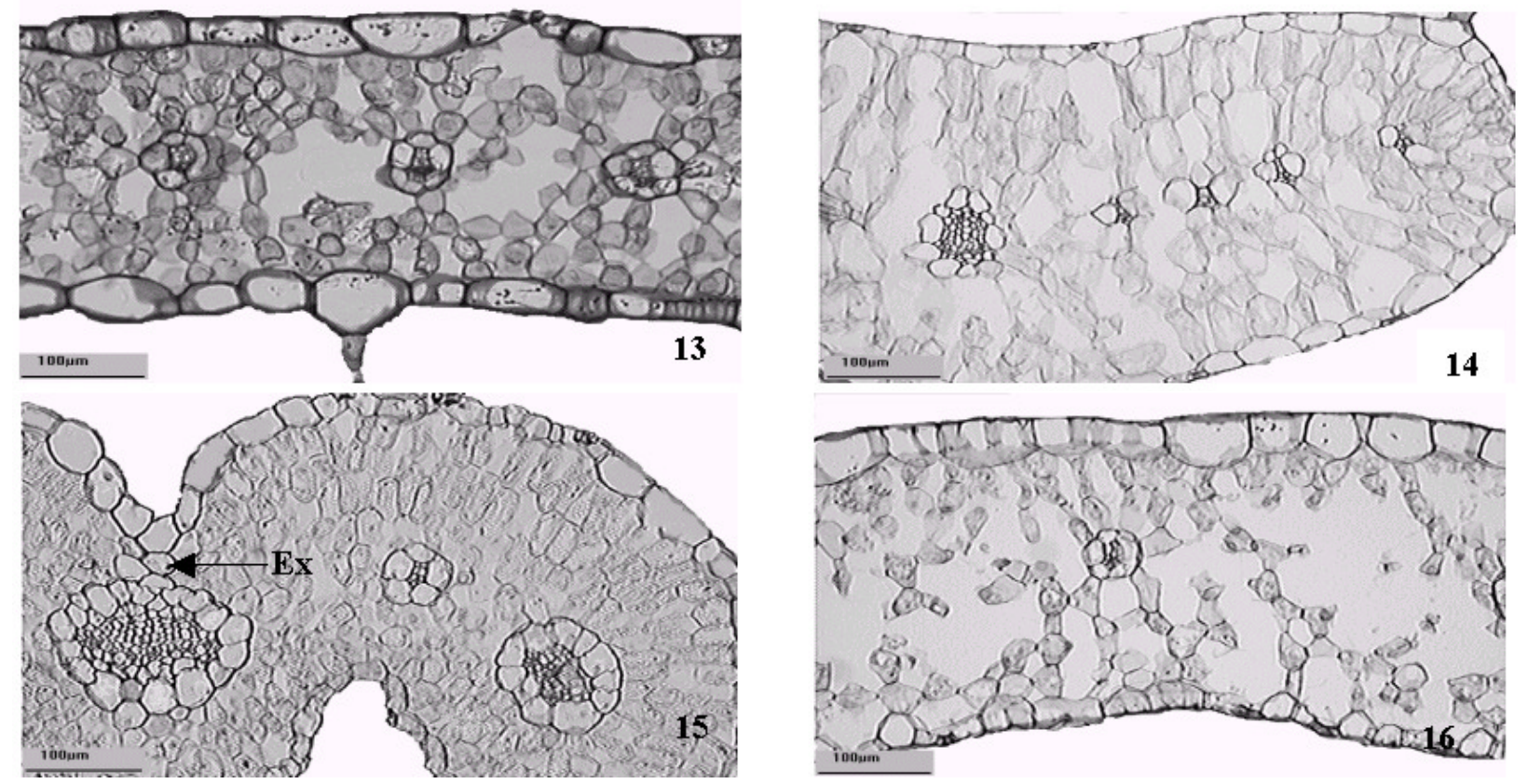

Figures 13-16 - Micrographs of the middle region of leaves of Calibrachoa in cross section. 13) C. ovalifolia, 14) C. pygmaea, 15) C. paranensis, 16) C. eglandulata. (Ex=bundle sheath extension).

Druse crystals, as described for some species of Solanaceae (Ogundipe, 1992; Cosa de Gastiazoro, $1991 ; 1993 ; 1994)$, were observed in the mesophyll of Calibrachoa sellowiana and $C$. caesia (Fig. 17). As the occurrence of the druse was restricted to two species, this characteristic has a taxonomic value, aiding in the determination of these taxa.

The vascular bundle sheath (endodermis) was formed by parenchymatous cells which wese bigger than those of the mesophyll (Fig. 1). In most of the species, the endodermis presented extension to both leaf surfaces in the median vein region (Fig. 15, Table 1). In C. micrantha leaves
(Fig. 16), the extension was only in the abaxial surface and, in C. paranensis (Fig. 15), only in the adaxial surface. In the leaves of $C$. heterophylla, C. humilis, C. parviflora, C. ericifolia and $C$. pygmaea (Fig. 6), the endodermis did not present any extensions.

Considering the characteristics of the epidermis (size of the cells and distribution of the stomata), the organization of the mesophyll (morphology and distribution of the chlorenchyma, extension of the endodermis) and the number of cells of the trichomes stalks (Table 1), we separated the species of Calibrachoa in the following way:

1. Non-glandular trichomes.

.C. eglandulata

1. Glandular trichomes.

2. Amphistomatic leaves.

3. Revolute leaves.

4. Epidermal cells of similar sizes on both leaf surfaces

C. paranensis

4. Larger epidermal cells on the adaxial surface.

C. ericifolia

3. Non-revolute leaves.

5. Semi-revolute leaves.

C. ovalifolia

5. Plane, conduplicate or semi-conduplicate leaves.

6. Homogeneous mesophyll.

7. Mesophyll with only lobed cells of spongy parenchyma.

7. Mesophyll with only by palisade parenchyma.

8. Trichome stalk with 1 to 3 cells. C. heterophylla

8. Trichome stalk with 2 to 4 cells C. pygmaea ..C. humilis 
6. Dorsiventral mesophyll.

9. Idioblast with druses in the mesophyll.

C. sellowiana

9. Characteristic lacking.

10. Mesophyll with adaxial palisade parenchyma and abaxial lobed cells of the spongy parenchyma....

C. spathulata

10. Mesophyll with adaxial palisade parenchyma and abaxial spongy parenchyma.

C. parviflora

2. Hypostomatic leaves.

11.Idioblast with druses in the mesophyll.

C. caesia

11. Characteristic lacking.

12. Revolute leaves......................................................... elegans

12. Semi-revolute or plane leaves.

13.Endodermis with an extension in the abaxial face in the median vein region

13. Endodermis with extension in both leaf surfaces in the median vein region

14. Dorsiventral mesophyll with adaxial palisade parenchyma and abaxial spongy parenchyma....

C. excellens

14. Dorsiventral mesophyll with adaxial palisade parenchyma and abaxial lobed cells of the spongy parenchyma.

15. Trichome stalk with 4 to 7 cells.

C. sendtneriana

15. Trichome stalk with 2 to 7 and 12 cells

C. linoides

Table 1 - Anatomical characteristics of the Calibrachoa leaves.

\begin{tabular}{|c|c|c|c|c|c|c|}
\hline SPECIES & $\begin{array}{l}\text { LEAF } \\
\text { TYPE }\end{array}$ & $\begin{array}{c}\text { STOMATA } \\
\text { OCCURRENCE }\end{array}$ & $\begin{array}{l}\text { EPIDERMAL } \\
\text { CELLS ASPECT }\end{array}$ & $\begin{array}{l}\text { MESOPHYLL } \\
\text { ORGANIZATION }\end{array}$ & $\begin{array}{c}\text { NUMBER OF } \\
\text { CELLS IN THE } \\
\text { GLANDULAR } \\
\text { TRICHOME: } \\
\text { STALKS }\end{array}$ & $\begin{array}{l}\text { ENDODERMIS } \\
\text { EXTENSION }\end{array}$ \\
\hline C. paranensis & $\mathrm{R}$ & A & $\mathrm{S}$ & $\mathrm{PL} / \mathrm{S}$ & $1-3$ & $\mathrm{AD}$ \\
\hline C. ericifolia & $\mathrm{R}$ & A & BA & $\mathrm{PL} / \mathrm{L}$ & $2-4$ & - \\
\hline C. ovalifolia & S-R & A & $\mathrm{S}$ & $\mathrm{L}$ & $2-5$ & B \\
\hline C. heterophylla & $\mathrm{P}$ & A & $\mathrm{S}$ & $\mathrm{L}$ & $2-5$ & - \\
\hline C. humilis & $\mathrm{P}$ & A & $\mathrm{S}$ & $\mathrm{P}$ & $2-4$ & - \\
\hline C. pygmaea & $\mathrm{P}$ & A & $\mathrm{S}$ & $\mathrm{P}$ & $1-3$ & - \\
\hline C. parviflora & $\mathrm{S}-\mathrm{C}$ & A & $\mathrm{S}$ & $\mathrm{PL} / \mathrm{S}$ & $2-4$ & - \\
\hline C. sellowiana $(1767) *$ & $\mathrm{~S}-\mathrm{C}$ & A & $\mathrm{S}$ & $\mathrm{PL} / \mathrm{L}$ & $2-4$ & B \\
\hline C. sellowiana $(1774) *$ & $\mathrm{~S}-\mathrm{C}$ & A & $\mathrm{S}$ & $\mathrm{PL} / \mathrm{L}$ & $1-6$ & B \\
\hline C. sellowiana $(1862) *$ & $\mathrm{~S}-\mathrm{C}$ & A & $\mathrm{S}$ & $\mathrm{PL} / \mathrm{L}$ & $3-4$ & B \\
\hline C. sellowiana $(1778) *$ & $\mathrm{P}$ & A & $\mathrm{S}$ & $\mathrm{PL} / \mathrm{L}$ & $2-4$ & B \\
\hline C. sellowiana $(1894) *$ & $\mathrm{C}$ & A & S & $\mathrm{PL} / \mathrm{L}$ & $2-5$ & B \\
\hline C. spathulata & $\mathrm{S}-\mathrm{C}$ & A & $\mathrm{S}$ & $\mathrm{PL} / \mathrm{L}$ & $2-6$ & B \\
\hline C. elegans & $\mathrm{R}$ & $\mathrm{H}$ & BA & $\mathrm{PL} / \mathrm{L}$ & $2-10$ & B \\
\hline C. caesia & $\mathrm{R}$ & $\mathrm{H}$ & BA & $\mathrm{PL} / \mathrm{L}$ & $1-5$ & B \\
\hline C. micrantha & $S-R$ & $\mathrm{H}$ & BA & $\mathrm{PL} / \mathrm{L}$ & $2-4$ & $\mathrm{AB}$ \\
\hline C. sendtneriana & S-R & $\mathrm{H}$ & BA & $\mathrm{PL} / \mathrm{L}$ & $4-7$ & B \\
\hline C. linoides $(1950) *$ & S-R & $\mathrm{H}$ & BA & $\mathrm{PL} / \mathrm{L}$ & $5-9,12$ & B \\
\hline C. linoides (1743)* & $\mathrm{P}$ & $\mathrm{H}$ & $\mathrm{BA}$ & $\mathrm{PL} / \mathrm{L}$ & $2-7,12$ & B \\
\hline C. excellens & $\mathrm{P}$ & $\mathrm{H}$ & BA & $\mathrm{PL} / \mathrm{S}$ & $1-6$ & B \\
\hline C. eglandulata & $\mathrm{P}$ & $\mathrm{H}$ & $\mathrm{BA}$ & $\mathrm{PL} / \mathrm{L}$ & - & B \\
\hline
\end{tabular}

Legends: R: revolute; S-R: semi-revolute; C: conduplicate; S-C: semi-conduplicate; A: amphistomatic; H: hypostomatic; S: similar; BA: big in the adaxial surface; PL: palisade parenchyma; S: spongy parenchyma; L: spongy parenchyma with lobed cells; AD: adaxial; B: both surfaces ; AB: abaxial; *: number of the collector.

\section{ACKNOWLEDGEMENTS}

This work was supported by CAPES.

\section{RESUMO}

Foram estudados, sob o ponto de vista anatômico, os limbos foliares de dezesseis espécies de Calibrachoa Llav. \& Lex. e de oito espécies de 
Petunia Juss. (Solanaceae). Em Calibrachoa, a bainha que envolve os feixes vasculares (endoderme) é formada por células desenvolvidas e distintas das do mesofilo. Em Petunia, esta bainha não apresenta diferenciação morfológica marcante. As folhas das espécies de Calibrachoa foram separadas entre si levando-se em conta a distribuição dos estômatos nas faces foliares, a organização do mesofilo, o tipo de bordo e a morfologia dos tricomas. Com base nesses resultados, foi elaborada uma chave dicotômica indentada de identificação para as espécies do gênero Calibrachoa.

\section{REFERENCES}

Ahmad, J. K. (1964), Cuticular studies in Solanaceae. Canadian Journal of Botany, 42, 773-803.

Ando, T. and Hashimoto, G. (1996), A new Brazilian species of Petunia (Solanaceae) from interior Santa Catarina and Rio Grande do Sul, Brazil. Brittonia, 48(2), 217-23.

Bernardello, L. M. (1982), Estudios en Lycium (Solanaceae) I. Anatomia de la hoja y tallo, y sus diferencias con Grabowskia. Boletin de la Sociedad Argentina de Botanica, 21(1-4), 153-185.

Brummitt, R. K. (1989), Report of the Committee for Spermatophyta: 36. Taxon, 38, 301.

Cosa de Gatiazoro, M. T. (1991), Estudio morfoanatomico de organos vegetativos em Cestroideae (Solanaceae), I: Tribu Nicotianeae. Kurtziana, 21, 111-152.

Cosa de Gastiazoro, M. T. (1993), Estudio morfoanatomico de organos vegetativos em Cestroideae (Solanaceae), II: Tribu Salpiglossideae. Kurtziana, 22, 47-72.

Cosa de Gastiazoro, M. T. (1994), Estudio morfoanatomico de organos vegetativos em Cestroideae (Solanaceae), III: Tribu Schwenckieae. Kurtziana, 23, 9-25.

Elliger, C. A.; Wong, R. Y.; Benson, M.; Gaffield, W. and Waiss, A. C. (1982), Diterpenes of Calibrachoa parviflora. Journal of Natural Products, 55, 14771487.

Fries, R. E. (1911), Die Arten der Gattung Petunia. Kongl. Svenska Vetenskapsakad. Handl., 461-472.

Heywwod, V. H. (1993), Flowering plants of the world. Oxford University Press, New York.

Hunziker, A. T. (1979), South American Solanaceae: a synoptic survey. In-The biology and taxonomy of the Solanaceae, ed. Hawkes, J. G.; Lester, R. N.; Skelding, A. D. American Press, London, pp. 49-85.

Johansen, D. A. (1940), Plant microtechnique. McGraw Hill Book Company, New York.
Metcalfe, C. R, and Chalk, L. (1957), Anatomy of the Dicotyledons II. Claredon Press, Oxford.

Ogundipe, O. T. (1992), Leaf epidermal studies in the genus Datura Linn. (Solanaceae), Phytomorphology, 42, 209-217.

Roe, K. E. (1971), Terminology of hairs in the genus Datura Linn. (Solanaceae), Taxon, 20(2), 501-508.

Sass, J. E. (1951), Botanical microtechnique. The Iowa State College Press, Iowa.

Sauer, J. D. (1994), Historical geography of crop plants. Roca Raton, Flórida.

Sink, K. C. (1984), Petunia. Springer - Verlag. pp. 1-9.

Stehmann, J. R. (1999), Estudos taxonômicos na tribo Nicotianeae G. Don (Solanaceae): revisão de Petunia Jussieu, das espécies brasileiras de Calibrachoa La Llave \& Lexarza e o estabelecimento de um novo gênero, Petuniopsis Stehmann \& Semir. Tese, Universidade Estadual de Campinas, Campinas, Brazil.

Stehmann, J. R. and Semir, J. (1997), A new species and new combinations in Calibrachoa (Solanaceae), Novon, 7, 417-419.

Watanabe, H.; Ando, T.; Nishino, E.; Kokubun, H.; Tsukamoto, T.; Hashimoto, G. and Marchesi, E. (1999), Three groups of species in Petunia sensu Jussieu (Solanaceae) inferred from the intact seed morphology. American Journal of Botany, 86(2), 302-305.

Wijnands, D. O; Bos, J. J.; Wijsman, W. J.; W, Schneider, F.; Brickell, C. D. and Zimmer, K. (1986), (856) Proposal to conserve 7436 Petunia with $P$. nyctaginiflora as typ. cons. (Solanaceae), Taxon, 35, 748-749.

Wijsman, H. J. W. (1982), On the Interrelationships of certain Species of Petunia. I. Taxonomic notes on the Parental Species of Petunia hybrida. Acta Botanica Neerlandica, 31, 477-490.

Wijsman, H. J. W. (1983), On the Interrelationships of certain Species of Petunia. II. Experimental Data: crosses between Different taxa. Acta Botanica Neerlandica, 32, 97-107.

Wijsman, H. J. W. (1990), On the inte-relationships of certain species of Petunia VI. New names for the species of Calibrachoa formely included into Petunia (Solanaceae), Acta Botanica Neerlandica, 39(1), 101-102.

Wijsman, H. J. W., Jong, J. H. (1985), On the interrelationships of certain species of Petunia IV. Hybridization between $P$. linearis and $P$. calycina and nomenclatorial consequenses in Petunia group. Acta Botanica Neerlandica, 34(3), 337-349.

Received: May 08, 2000; Revised: August 30, 2000; Accepted: March 12, 2001. 